\title{
SHARP INEQUALITIES FOR HERMITIAN TOEPLITZ DETERMINANTS FOR STRONGLY STARLIKE AND STRONGLY CONVEX FUNCTIONS
}

\author{
Bogumita KowAlCZYK, AdAM LECKO* AND BARBARA ŚMIAROWSKA
}

Abstract. Sharp upper and lower bounds are found of the second and third order Hermitian Toeplitz determinants for the classes of strongly starlike and strongly convex functions of order $\alpha(\alpha \in[0,1))$.

Mathematics subject classification (2010): 30C45, 30C50.

Keywords and phrases: Hermitian Toeplitz determinant, strongly starlike function, strongly convex function, Carathéodory class.

\section{REFERENCES}

[1] J. W. AleXANDER, Functions which map the interior of the unit circle upon simple regions, Ann. of Math., 17, (1915), 12-22.

[2] Md Firoz Ali, D. K. Thomas, A. Vasudevarao, Toeplitz determinants whose elements are the coefficients of analytic and univalent functions, Bull. Austr. Math. Soc., 97, 2 (2018), 253-264.

[3] R. M. ALI, V. SINGH, On the fourth and fifth coefficients of strongly starlike functions, Results Math., 29, (1996), 197-202.

[4] D. A. Brannan, W. E. Kirwan, On some classes of bounded univalent functions, J. London Math. Soc., 2 (1), (1969), 431-443.

[5] C. CARATHÉODORY, Über den Variabilitatsbereich der Koeffizienten von Potenzreihen, die gegebene werte nicht annehmen, Math. Ann., 64, (1907), 95-115.

[6] N. E. Cho, B. Kowalczy K, O. S. Kwon, A. Lecko, Y. J. Sim, Some coefficient inequalities related to the Hankel determinant for strongly starlike functions of order alpha, J. Math. Ineq., 11, 2 (2017), 429-439.

[7] N. E. CHO, B. KowALCZYK, A. LECKO, Sharp bounds of some coefficient functionals over the class of functions convex in the direction of the imaginary axis, Bull. Aust. Math. Soc., 100, (2019), 86-96.

[8] K. Cudna, O. S. Kwon, A. Lecko, Y. J. Sim, B. Śmiarowska, The second and third-order Hermitian Toeplitz determinants for starlike and convex functions of order $\alpha$, Boletin Soc. Mat. Mex., 26, (2020), 361-375.

[9] A. W. Goodman, Univalent Functions, Mariner, Tampa, Florida, 1983.

[10] B. Kowalczy K, O. S. Kwon, A. Lecko, Y. J. Sim, B. Śmiarows Ka, The third-order Hermitian Toeplitz determinant for classes of functions convex in one direction, Bull. Malays. Math. Sci. Soc., 43, (2020), 3143-3158.

[11] B. KowalczYK, A. Lecko, Y. J. Sim, The sharp bound of the Hankel determinant of the third kind for convex functions, Bull. Aust. Math. Soc., 97, (2018), 435-445.

[12] O. S. KWON, A. LECKO, Y. J. Sim, B. ŚmiarowsKa, The sharp bound of the fifth coefficient of strongly starlike functions with real coefficients, Bull. Malays. Math. Sci. Soc., 42, 4 (2019), 17191735.

[13] A. Lecko, Some Methods in the Theory of Univalent Functions, Oficyna Wydawnicza Politechniki Rzeszowskiej, Rzeszów, 2005.

[14] A. Lecko, Strongly starlike and spirallike functions, Ann. Polon. Math., 85, 2 (2005), 165-192.

[15] W. MA, D. MINDA, An internal geometric characterization of strongly starlike functions, Ann. Univ. Mariae Curie Skłodowska Sect. A, 20, (1991), 89-97.

[16] W. MA, S. OwA, Strongly starlike functions, Panam. Math. J., 3, 2 (1993), 49-60. 
[17] R. Nevanlinna, Über die konforme Abbildung von Sterngebieten, Översikt av Finska Vetens.-Soc. Förh., Avd. A, LXIII, 6 (1920-1921), 1-21.

[18] C. Pommerenke, Univalent functions, Vandenhoeck \& Ruprecht, Göttingen, 1975.

[19] E. STUDY, Vorlesungen über ausgewählte Gegenstände der Geometrie, Zweites Heft; Konforme Abbildung Einfach-Zusammenhängender Bereiche, Druck und Verlag von B. G. Teubner, Leipzig und Berlin, 1913.

[20] J. Stankiewicz, Quelques problèmes extrémaux dans les classes des fonctions $\alpha$-angulairement étoilées, Ann. Univ. Mariae Curie-Skłodowska Sect. A, 20, (1966), 59-75.

[21] J. Stankiewicz, On a family of starlike functions, Ann. Univ. Mariae Curie-Skłodowska Sect. A, 22-24, (1968-1970), 175-181.

[22] T. SugAWA, A self-duality of strong starlikeness, Kodai Math. J., 28, (2005), 382-389. 